\title{
U.S. Geological Survey Programs in Mississippi
}

\section{U.S. Department of the Interior - U.S. Geological Survey}

For more than 100 years the U.S. Geological Survey (USGS) has provided earth-science information to help others understand and manage the Nation's energy, land, mineral, biological, and water resources. Such information is used in many decisions regarding management and optimum use of Mississippi's natural resources and to address major environmental, economic, and health issues, such as contamination of the environment by hazardous wastes, adequacy of suitablequality water supplies, nutrient input to streams and estuaries, distribution of coal and mineral resources, and effects of urban development and agriculture on the environment.

\section{Bridge-Site Evaluations}

The U.S. Geological Survey works closely with the Mississippi Department of Transportation (MDOT). USGS streamflow records, hydrologic analyses of basins, and hydraulic analyses of flooding potential at proposed highway bridges provide information used by the MDOT to design those bridges.

Flood-frequency and hydraulic characteristics at highway bridges are determined from historic flood elevations recovered by the USGS, cross-section data, and correlations with nearby gaging stations. Streamflow data are collected to define the hydraulic characteristics of other ungaged sites as requested by the MDOT. This information provides the basis for the design of highways and drainage structures, and it is used by local agencies and the general public to guide floodplain management.

During 1993-96, the USGS completed 264 bridge-site studies; in 1996, 104 such studies were completed. Many of the analyses were for multiple bridge openings.

Also, statistical analyses of streamflow data were provided as requested by the MDOT.
Streambanks and channel scour near bridge piers and abutments (fig. 1) during floods has resulted in more bridge failures than all other causes in recent history. The design and maintenance of bridge foundations require consideration of the maximum depth of scour that could occur during an extreme flood.

In 1993, the USGS, in cooperation with the MDOT, began a 5-year study to evaluate observed and potential scour conditions at selected bridges. Since 1993, the USGS has completed 102 scour-evaluation studies.

\section{Surface-Water Investigations}

The USGS has collected surface-water data in Mississippi since 1899. These data are stored in computerized local and national data bases and disseminated to cooperators, educational institutions,

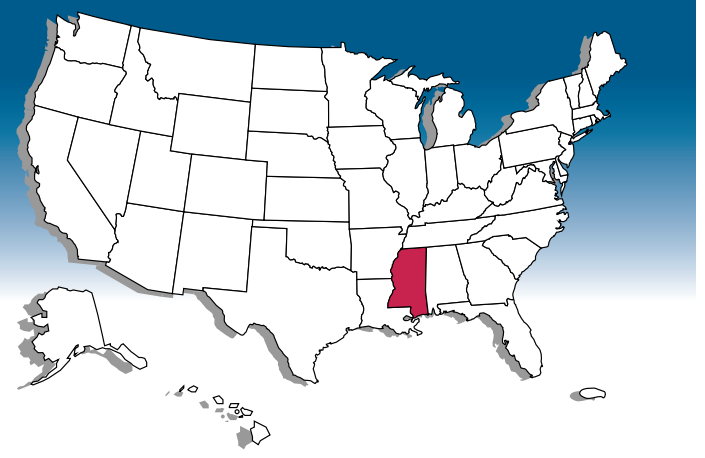
Index of Subjects
Bridge-Site Evaluations
Surface-Water Investigations
Ground-Water Investigations
Erosion Control
Water-Quality Assessment
Ecological Research
Topographic Mapping
Geologic Information
Oil and Gas Assessment
National Coal Assessment
Agricultural Management-Systems
Evaluation
Geologic Mapping
Digital Mapping
Cooperative Programs and Partnership

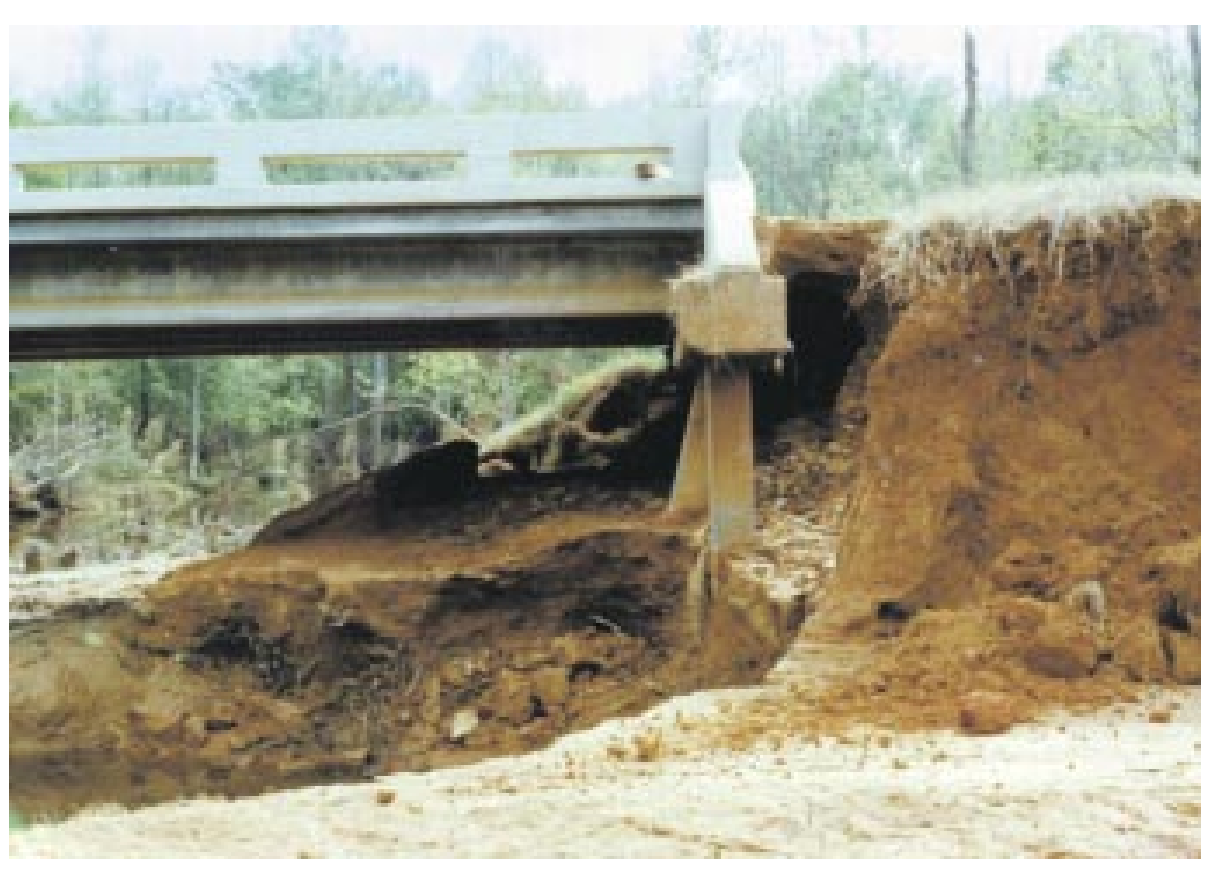

Figure 1. An example of bridge-abutment scour in central Mississippi. 
private organizations, and the public in published reports, and by the Internet. In addition, the USGS responds to thousands of data requests from the general public each year.

The current surface-water data-collection program in Mississippi provides continuous stage and discharge information for 88 sites, continuous stage information for an additional 7 sites, and periodic stage and discharge information for 59 other sites.

As of January 1997, 83 of 96 continuously recording streamflow gaging stations were equipped with satellite transmitters. In 1995 the USGS became one of the first organizations to apply this technology to the Internet by developing a real-time Surface Water Data page that provides tabular and graphic forms of continuously updated stage and discharge data, in addition to long-term flow statistics and a gage description. To view or retrieve these data on the Internet, go to:

http://water.usgs.gov/swr/MS/

With significant advancement of acoustic-signal processing, it is possible to profile three-dimensional velocity vectors with a high degree of precision and repeatability. Recently the USGS began using an acoustic Doppler current profiler to measure discharge at sites on some of the larger rivers in Mississippi. This method is used to model three-dimensional velocity near bridges, dams, and other flow-control structures to document effects of tidal flow and backwater conditions on rivers (fig. 2).

\section{Ground-Water Investigations}

Ground water supplies 80 percent of all the freshwater used in Mississippi. Increasing population and the accompanying economic growth are expected to increase the demand for freshwater. The USGS, in cooperation with State and local agencies, investigates ground-water resources in Mississippi.

In northeastern Mississippi, most ground water is supplied by the EutawMcShan aquifer and the Tuscaloosa aquifer system. A digital model developed by the USGS is being used to simulate flow in the aquifer system to understand the resource and its capacity. The model is being expanded to include the Coffee Sand and Paleozoic aquifers.

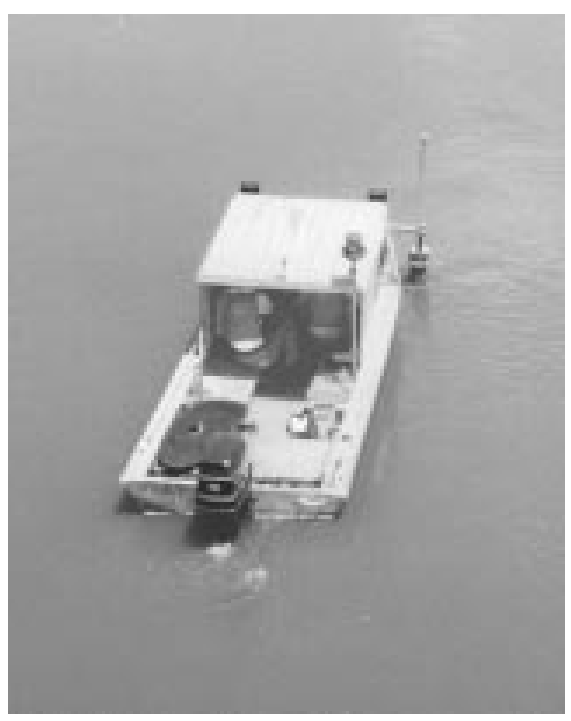

Figure 2. Using an acoustic Doppler current meter to collect three-dimensional velocity data.

In coastal Jackson County, the location and depth of water-bearing sands were compiled and mapped by interpreting more than 1,600 well lithology records. Information determined from each record was entered into a geographic information system (GIS) data base.

\section{Erosion Control}

In 1984, Congress directed the U.S. Army Corps of Engineers and the Soil Conservation Service, now the Natural Resource Conservation Service, to establish demonstration watersheds for studying erosion and sedimentation in agricultural watersheds. The Demonstration Erosion Control project is in the upper Yazoo River Basin in north-central Mississippi. The project is an ongoing, multiagency effort for planning, constructing, and evaluating projects to alleviate erosion, sedimentation, and flooding problems in the bluff hills that border the Mississippi River alluvial plain, known locally as the "Delta". Analyses of the data by the USGS have identified trends in stream discharge, suspended-sediment concentration, and sediment discharge data for several of the sites.

\section{Water-Quality Assessment}

The goals of the National Water-Quality Assessment (NAWQA) Program are to describe trends in the quality of a large part of the Nation's water resources and to identify the major natural and human factors that affect the quality of these resources. Assessment of the Mississippi Embaymant study unit, which covers an area of about 49,800 square miles, and includes parts of Arkansas, Kentucky, Louisiana, Mississippi, Missouri, and Tennessee, began in 1994. Much of the NAWQA work is done at more than 160 sites selected to represent a broad spectrum of land-use conditions.

The occurrence and distribution of common inorganic constituents, trace elements, nutrients, and pesticides and other organic compounds in surface and ground water are bring investigated. The amounts of nutrients and suspended sediment being transported by streams are being determined (fig. 3). Ecological characteristics of the area including assessment of algal, fish, and aquatic macroinvertibrate communities are being evaluated as integrated indicators of water quality. Organochlorine compounds, PCB's (polyclorinated biphenyls), and trace elements are measured in fish tissue and in bed sediments.

\section{Ecological Research}

The USGS recently began a project with the U.S. Environmental Protection Agency that will use GIS to assist Federal, State, and local agencies to prioritize their wetlands restoration efforts. The project will use information such as soil type, amount

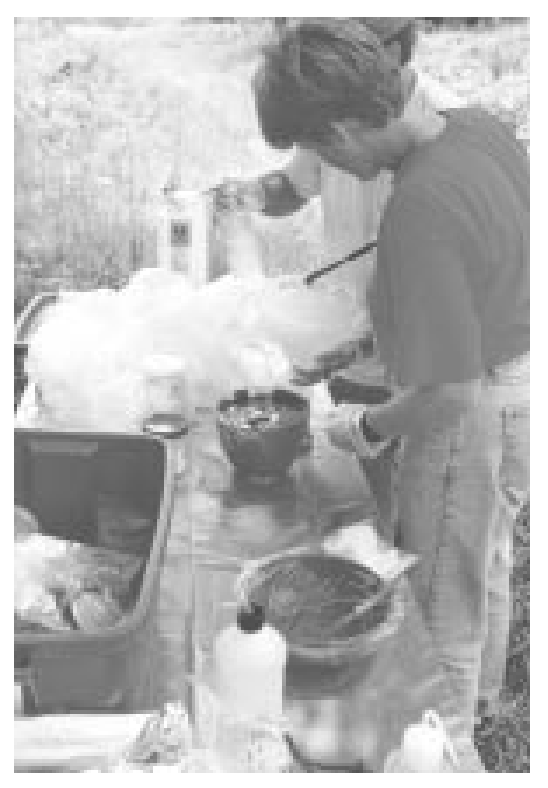

Figure 3. Processing sediment samples for trace element analysis. 
of time areas are flooded, vegetative cover, and digital terrain models to assess the likelihood that an area could be restored to a functional wetland.

Other wetland studies are being conducted in Mississippi by the USGS National Wetlands Research Center in Lafayette Louisiana. Bottomland hardwood reforestation research at Yazoo National Wildlife Refuge is designed to assist managers in improving restoration success in farmed wetlands of the Delta Region. The effects of fire on the restoration of the longleaf pine savanna that the sandhill cranes require for habitat are being studied at the Mississippi Sandhill Crane National Wildlife Refuge.

The USGS Mississippi Cooperative Fish and Wildlife Research Unit is located at Mississippi State University in Stakrville. Research encompasses sport-fish-population dynamics, ecology and management of lower Mississippi river fishes, and the conservation biology of sensitive species in Mississippi and the Caribbean. Other studies include collaboration with State agencies and the Delta Wildlife Foundation on survival of largemouth bass and in providing the Catfish Farmers of America information to reduce losses of fish to fisheating birds. The USGS Patuxent Wildlife Research Center field station at Vicksburg is studying the response of waterfowl and migrant birds to land-use management strategies.

\section{Topographic Mapping}

Among the most popular and versatile products of the USGS are 1:24,000-scale topographic maps (1 inch on the map represents 2,000 feet on the ground). Some of the map data are available in digital formats. These maps depict basic natural and cultural features of the landscape, such as lakes and streams, highways and railroads, boundaries, and geographic names. Contour lines are used to depict the elevation and shape of terrain. Mississippi is covered by 850 maps at this scale, which is useful for civil engineering, land-use planning, natural-resource monitoring, and other technical applications. These maps have long been favorites with the general public for outdoor uses, including hiking, camping, exploring, and back-country fishing expeditions.
The USGS National Mapping Program has developed a new agreement with Mississippi Automated Resources Information Systems (MARIS) for producing Digital Tagged Vector Contour Data (TVC). The USGS is supplying MARIS with elevation contours in exchange for the completed level-2 tagged vector contour data. TVC's are an intermediate product used for developing Digital Elevation Models (DEM's) as well as Digital Line Graph Hypsography.

\section{Geologic Information}

The USGS operates Geologic Information Centers; many of the topics they focus on are of interest to people in Mississippi. The National Earthquake Information Center (NEIC) in Golden, Colorado, is deploying the U.S. National Seismograph Network (USNSN), which, when completed, will consist of about 60 seismograph stations nationwide. The USNSN monitors nationwide seismicity, provides early notification of seismic events to national-level emergency-services personnel, maintains an archive of high-quality digital data on national seismicity, and provides public information. A USNSN station in Oxford, Mississippi, sends data by satellite telemetry to the NEIC.

\section{Oil and Gas Assessment}

Much of southern Mississippi lies in the Gulf Coast region. This region has a long history of producing large amounts of petroleum and is experiencing a resurgence of interest in exploring for petroleum trapped around and underneath large subsurface salt structures. The USGS recently began a study of these structures to understand how they were formed and to evaluate their potential for containing trapped petroleum.

\section{National Coal Assessment}

Coal accounts for about one-fourth of the total energy and more than one-half of the electricity generated in the United States. Even with substantial increases in energy conservation and in natural gas use to meet increased demands for energy, coal will continue to be a major contributor. New technologies to use coal will require resources that fit explicit quality requirements. Therefore, information about the location, quantity, and quality of the Nation's coal resources to be consumed during the next 20 years, classified particularly by best end use, will be needed by national and regional planners. In the National Coal Assessment, the USGS will work with the Mississippi Office of Geology to identify the location and quality of coal resources, including coal that may be suitable for export, on public and private lands. The USGS is working with several Federal and State agencies to aid Mississippi and its industry to develop cost-effective strategies to mitigate acid-rain and acidic mine drainage problems that are associated with coal burning and mining and to remedy present contamination.

The USGS STATEMAP program is supporting detailed mapping in east-central Mississippi where economically significant deposits of lignite are being considered for power generation. Lignite production will require strip mining and construction of a power plant. This part of the State also is a recharge area for an important aquifer where protection of the ground-water supply is necessary. The project also is studying the distribution and extent of potentially economic ceramic clay.

\section{Agricultural Management- Systems Evaluation}

The Mississippi Delta Management Systems Evaluation Area project is an interagency 5-year study to assess how agricultural activities affect the water resources in the Delta and to increase the knowledge needed to design and evaluate management practices as components of farming systems. The study is being conducted at sites within three Delta oxbowlake watersheds, where cotton production is the primary land use.

\section{Geologic Mapping}

The USGS, in cooperation with the Surface Geology Division of the Mississippi Office of Geology, is working through the STATEMAP program to map the subsurface geology in north-central Mississippi. Shallow aquifers in these units could be affected by proposed development of a lignite stripmine and an electric power generating plant. The geology of 16 quadrangles, including parts of Choctaw, Oktibbeha, Winston, Montgomery, Attala, Webster, Calhoun, and Grenada Counties, will be mapped. In this area, several towns depend on ground water for their water supply. 
The Surface Geology Division also has received USGS National Coal Resources Data System (NCRDS) grants for 1996 and 1997. Lignite seams found in recent core been added to the NCRDS data base.

\section{Digital Mapping}

The USGS and the National Park Service (NPS) have established an interagency agreement to produce digital raster graphics (DRG) for barrier islands along the Mississippi Gulf Coast. The DRG's are scanned from USGS topographic maps, and can be used as an accurate base for a GIS. A private company is producing the DRG's for the USGS and participating agencies under a Federal-private partnership. DRG's will be prepared for all 1:24,000-, $1: 100,000-$, and 1:250,000-scale topographic maps covering the NPS area of interest. The USGS and the NPS also are cooperating to produce digital line graph, DEM's, and digital orthophotoquad data for the Gulf Islands National Lakeshore.

The USGS has joined the U.S. Army Corps of Engineers, Vicksburg, and the U.S. Department of Agriculture Natural Resources Conservation Service to fund completion of the 206 remaining 1:24,000-scale DEM's for Mississippi. The models can be used for topographic visualization (fig. 4). When complete, Mississippi will have an accurate, Statewide digital topographic data base suitable for GIS analysis. holes and in about 90 drilling records have

\section{Cooperative Programs and Partnerships}

The work of the USGS in Mississippi is accomplished in part through cooperation with local, State, and other Federal agencies who share in the planning and financial support of the program. Agencies that provided funding and services in support of the USGS activities during 1995-97 include: the City of Jackson; the Harrison County Board of Supervisors; the Harrison County Development Commission; the Jackson County Board of Supervisors; the Jackson Port Authority; the Gulf States Marine Fisheries Commission; the Mississippi Automated Resource Information System; the Mississippi Department of Agriculture and Commerce; the Mississippi Department of Environmental Quality, the Office of Land and Water Resources, the Office of Geology, and the Office of Pollution Control; the Mississippi Department of Health; Mississippi State University; the Mississippi Department of Transportation; the Mississippi Soil and Water Conservation Commission; the Pat Harrison Waterway District; the Pearl River Basin Development District; the Pearl River Valley Water Supply District; the Yazoo Mississippi Delta Joint Water Management District; the National Park Service; the U.S. Army Corps of Engineers, Mobile and Vicksburg Districts; the U.S. Environmental Protection Agency; the U.S. Department of Agriculture, Natural Resources Conservation Service, and the Agricultural Research Service; the Mississippi Water Resources Research Institute; and the Mississippi Rural Water Association.

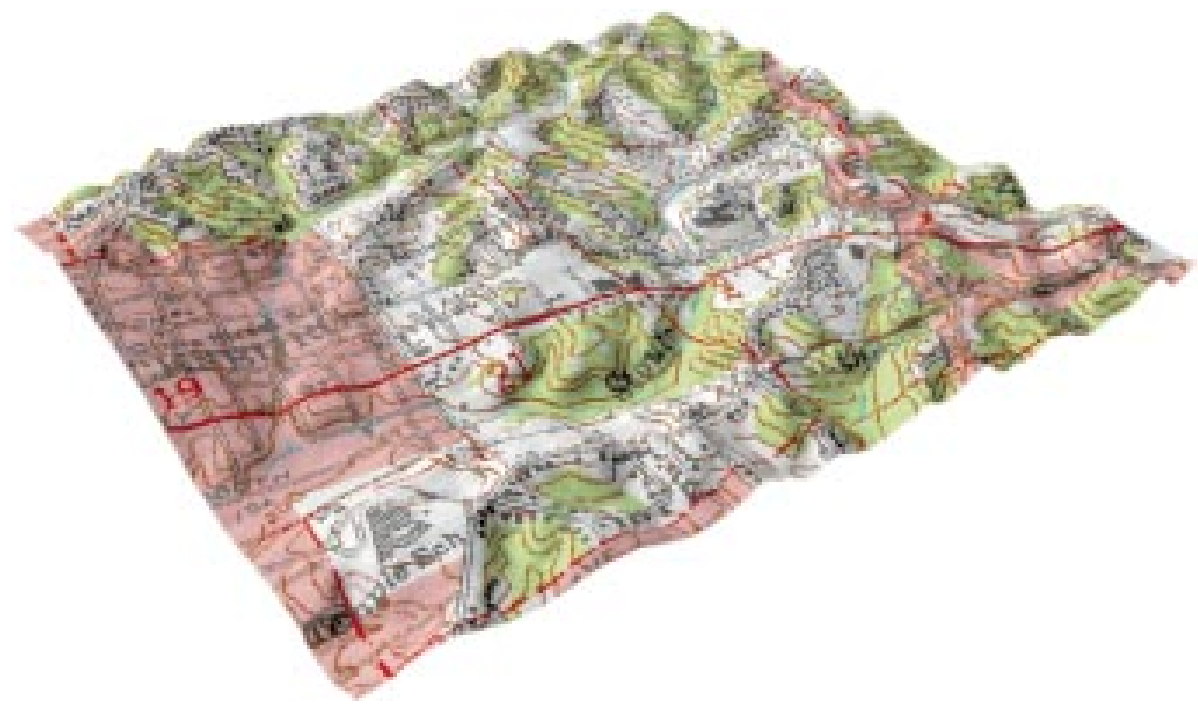

Figure 4. Aerial perspective of the terrain at Vicksburg with a topographic map superimposed upon it to aid visualization. (Created from digital raster graphic and digital elevation model data.)
For More Information
USGS state representative
308 South Airport Road
Pearl, MS 39208
$(601) 965-4600$
Fax: (601) 965-5782
Email: dc_ms@usgs.gov

Additional earth science information can be found by accessing the USGS Home Page on the World Wide Web at http://www.usgs.gov/

For more information on all USGS reports and products (including maps, images, and computerized data), call 1-800-USA-MAPS
The USGS provides maps, reports, and information to help others meet their needs to manage, develop, and protect America's water, energy, mineral, biological, and land

resources. We help find the natural resources needed to build tomorrow, and supply the scientific understanding needed to help minimize or mitigate the effects of natural hazards and environmental damage caused by natural and human activities. The results of our efforts touch the daily life of almost every American. 